\title{
EFFECT OF UNILATERAL OVARIECTOMY ON TWINNING FREQUENCY IN THE MARMOSET
}

\author{
N. GENGOZIAN AND G. B. MERRITT* \\ Medical Division, Oak Ridge Associated Universities, Oak Ridge, Tennessee, U.S.A.
}

(Received 20th Fune 1970)

The marmosets, small New World primates of the family Callithricidae, were reported by Wislocki (1939) to have a high frequency of fraternal twinning. On the basis of information obtained from an examination of nineteen pregnant specimens and observations on an additional twenty-one cases reported by others, Wislocki (1939) calculated an $87.5 \%$ incidence of twinning. Breeding data obtained in our colony over the past 5 years have substantiated this twinning phenomenon. In 261 recorded deliveries, there have been $77 \%$ twins, $5 \%$ triplets, and $18 \%$ single births (Gengozian, 1970), and the sexes of the twins approximate to those expected for fraternal twinning, i.e. $1(\mathrm{~mm})$ : $2(\mathrm{mf}): 1$ (ff). Another unique facet of the marmoset's physiology is the extensive placental vascular connection which invariably exists between the twin foetuses; Hill \& Hill (1927) noted this briefly and later Hill (1932) and Wislocki (1939) documented it in greater detail. Haemopoietic chimaerism, a consequence of the prenatal anastomoses, was subsequently found in imported adult marmosets by Bernirschke, Anderson \& Brownhill (1962) and by Gengozian, Batson \& Eide (1964). To date, we have found chimaerism in all heterosexual co-twin pairs, reflecting the consistent development of the vascular anastomoses (Gengozian, Batson, Greene \& Gosslee, 1969; Gengozian, 1969). Although single births occur, studies in our laboratory indicate that these animals may also be blood chimaeras (Gengozian, 1969; Gengozian et al., 1969). This latter observation may be explained by the death and resorption of one twin foetus after contributing primordial cells to its co-twin; we have obtained evidence for the induction of chimaerism by this means (Gengozian et al., 1969). Multiple young, therefore, are conceived at a frequency greater than that recorded at term.

On the basis of the preceding information, it must be assumed that all marmosets, even single born, have a high probability of being haemopoietic chimaeras. In certain experimental situations, however, it would be desirable or even necessary to have an 'abnormal' marmoset, i.e. one that is not a blood chimaera. For example, since detection of chimaerism depends on sex markers and is therefore limited to members of heterosexual pairs, efforts in our laboratory have been directed toward defining red blood cell antigens to evaluate erythrocyte chimaerism (Gengozian, 1966). Iso-immunizations have been successful, but the absence of known non-haemopoietic chimaeras has

* Present address: National Institutes of Health, Bethesda, Maryland. 
curtailed efforts to develop monospecific reagents. A method of procuring non-chimaeric single young was suggested by an early report of Hill \& Hill (1927) who had noted that in two sets of pre-somite twins, ovulation was bilateral, i.e. each ovary had a single corpus luteum. This was later confirmed by Wislocki (1939) in an examination of an additional seven sets of ovaries. These observations raised the possibility that the development of a single zygote, and therefore a potential non-chimaera, could be achieved by removal of one ovary.

Left unilateral ovariectomies (confirmed on subsequent histological examinations of the tissue) were performed on six Saguinus fuscicollis marmosets and the results of breeding these animals over a 3-year period are shown in Table 1.

TABLE 1

OFFSPRING PRODUCED BY MARMOSETS AFTER UNILATERAL OVARIEGTOMY

\begin{tabular}{|c|c|c|c|c|c|}
\hline \multirow{2}{*}{$\begin{array}{c}\text { Female } \\
\text { no. }\end{array}$} & \multirow{2}{*}{$\begin{array}{c}\begin{array}{c}\text { Date of } \\
\text { ovariectomy }\end{array} \\
18 / 7 / 66\end{array}$} & \multicolumn{4}{|c|}{$\begin{array}{c}\text { Breeding results: } \\
\text { date of delivery, no. and sex of offspring }\end{array}$} \\
\hline & & $\begin{array}{l}16 / 8 / 67 \\
2-\mathbf{M}, \mathbf{F}\end{array}$ & $\begin{array}{l}20 / 5 / 68 \\
2-M, F\end{array}$ & $\begin{array}{l}22 / 2 / 69 \\
2-\mathrm{F}, \mathrm{F}\end{array}$ & $\begin{array}{l}\text { 9/10/69 } \\
\text { 3-M, M, F }\end{array}$ \\
\hline 2 & $18 / 7 / 66$ & $\begin{array}{l}29 / 12 / 66 \\
2-M, F\end{array}$ & $\begin{array}{l}10 / 7 / 67 \\
2-\mathrm{M}, \mathrm{F}\end{array}$ & $\begin{array}{l}31 / 3 / 69 \\
1-\mathbf{M}^{*}\end{array}$ & \\
\hline 3 & $23 / 8 / 66$ & $\begin{array}{l}2 / 7 / 67 \\
1-? \dagger\end{array}$ & $\begin{array}{l}30 / 12 / 68 \\
1-? \dagger\end{array}$ & & \\
\hline 4 & $19 / 7 / 66$ & $\begin{array}{l}5 / 7 / 67 \\
1-? \dagger\end{array}$ & & & \\
\hline $5 \ddagger$ & $25 / 11 / 66$ & $\begin{array}{l}22 / 9 / 67 \\
2-\mathrm{M}, \mathrm{F}\end{array}$ & $\begin{array}{l}21 / 4 / 68 \\
2-M, M\end{array}$ & $\begin{array}{l}25 / 12 / 68 \\
2-\mathbf{M}, \mathbf{M}\end{array}$ & $\begin{array}{l}11 / 7 / 69 \\
2-F, F S\end{array}$ \\
\hline $6 \ddagger$ & $25 / 11 / 66$ & - & & & \\
\hline
\end{tabular}

* This single born male was chimaeric for female cells as revealed by analysis of the sex chromosomes.

$\dagger$ Pregnancy terminated in abortion; only one embryo, sex unknown, could be found. Two yolk sacs were found with placenta of $2 / 7 / 67$ abortion.

$\ddagger$ Females had delivered twins some time before the operation, No. 5 three times and No. 6 once.

$\S$ Both young were full-term stillborn.

Fourteen pregnancies occurred in five of the six females. Three of these terminated in early abortion and in each, only a single embryo was found. However, in one placenta, two yolk sacs could be identified. Of the eleven pregnancies that went to term, only one yielded a single young. This animal, a male, was, however, a blood chimaera as revealed by the identification of female cells by chromosomal analysis. One pregnancy yielded triplets, two males and a female. Of the nine twins delivered, six were heterosexual pairs. Two marmosets used in this experiment had produced twins before unilateral ovariectomy was performed; one continued to do so after the operation, while the other has since failed to become pregnant.

The twinning frequency and sexes recorded from this small group of animals compares with that observed in our colony for a much larger group of intact breeding females. It would, therefore, seem that removal of one ovary does not interfere with the multiple ovulation breeding pattern of these animals. 
Although three abortions occurred, they cannot be attributed to the ovariectomized condition since similar interrupted pregnancies have been observed in several of our intact breeding females.

The results of this study are perhaps not surprising in view of the fact that in many polytocous non-primate species, unilateral ovariectomy is known to lead to an increase in the rate of follicular maturation in the remaining ovary, so that the number of corpora lutea formed does not differ significantly from that of intact females (Lipschutz \& Adamberg, 1925; Biggers, Finn \& McLaren, 1962). The mechanism of this phenomenon, referred to as the 'law of follicular constancy' (Lipschutz, 1928), is still not known. However, two hormonal pathways have been suggested: (a) removal of one ovary causes an increase in the release of pituitary gonadotrophins (Edgren, Parlow, Peterson \& Jones, $1965)$; or (b) removal of one ovary exposes the remaining ovary to greater amounts of gonadotrophins without an increased release from the pituitary (Zarrow, Sundaram \& Storb, 1965). Data by Short, Peters, First \& Casida (1968) support the former suggestion. In any event, it is apparent that the marmoset, unique among primates in its high incidence of multiple births, also exhibits some trophic response after unilateral ovariectomy. It might be possible, therefore, to achieve 'true' single young by the transplantation rather than the removal of one ovary, so that the vascular network and any pituitaryovarian hormonal feedback mechanisms were not altered, and ova from the transplanted ovary could not be fertilized. Experiments designed to test this method are in progress.

This work was supported in part by United States Public Health Service Grant ROI AMO 9289-03, 04, 05 AIB from the National Institutes of Health and by the United States Atomic Energy Commission. C.B.M. was a Summer Student Trainee from Tulane University School of Medicine, New Orleans, Louisiana.

\section{REFERENCES}

Benirschke, K., Anderson, J. M. \& Brownhill, L. E. (1962) Marrow chimerism in the marmosets. Science, N.Y. 138, 513.

Biggers, J. D., FinN, G. A. \& McLaren, A. (1962) Long-term reproductive performance of female mice, II. Variation of litter size with parity. F. Reprod. Fert. 3, 313.

Edgren, R. A., Parlow, A. F., Peterson, D. L. \& Jones, R. C. (1965) On the mechanism of ovarian hypertrophy following hemicastration in rats. Endocrinology, 76, 97.

Gengozian, N. (1966) Formation of isohaemagglutinins in the marmoset, Tamarinus nigricollis. Nature, Lond. 209, 722.

Gengozian, N. (1969) Marmosets: their potential in experimental medicine. Ann. N.Y. Acad. Sci. $162,336$.

Gengozian, N. (1970) Male and female cell populations in the chimeric marmoset. Proc. 2nd Conf. Exp. Med. and Surg. in Primates, September, 1969, New York (In press).

Gengozian, N., Batson, J. S. \& EIDE, P. (1964) Hematologic and cytogenetic evidence for hematopoietic chimerism in the marmoset, Tamarinus nigricollis. Cytogenetics, 3, 384.

Gengozian, N., Batson, J. S., Greene, G. T. \& Gosslee, D. (1969) Hemopoietic chimerism in imported and laboratory-bred marmosets. Transplantation, 8, 633.

Hril, J. P. (1932) II Groonian Lecture. The developmental history of the primates. Phil. Trans. R. Soc. B, 221, 45 .

Hill, J. P. \& Hill, C. J. (1927) An early blastocyst of Hapale. C.r. Ass. Anat. 22, 264.

Lipschutz, A. (1928) New developments in ovarian dynamics and the law of follicular constancy. Br. F. exp. Biol. 5, 283. 
Lipschutz, A. \& ADAmberg, L. (1925) Nouvelles expériences sur la loi de la constance folliculaire C.r. Séanc. Soc. Biol. 93, 1464.

Short, R. E., Peters, J. B., First, N. L. \& Casida, L. E. (1968) Effect of exogenous progesterone and unilateral ovariectomy on ovarian and pituitary gland activity. 7. Anim. Sci. 27, 705.

WisLockI, G. B. (1939) Observations on twinning in marmosets. Am. F. Anat. 64, 445.

Zarrow, M. X., Sundaram, S. K. \& Storb, M. (1965) pMs-induced ovulation in the immature rat following unilateral castration. Proc. Soc. exp. Biol. Med. 119, 331. 